\title{
DETERMINATION OF ANTIOXIDANT CAPACITY AND GALLIC ACID CONTENT IN ETHANOLIC EXTRACT OF PUNICA GRANATUM L. LEAF
}

\author{
SREEDEVI P, VIJAYALAKSHMI K* \\ Department of Biochemistry, Bharathi Women's college, Chennai, Tamil Nadu, India. Email: viji42research@yahoo.co.in
}

Received: 07 November 2017, Revised and Accepted: 15 December 2017

\begin{abstract}
Objective: The present research work was carried out to evaluate the antioxidant potential of ethanolic extract of Punica granatum leaf (EPGL) that belongs to the family of Punicaceae and determine its gallic acid (GA) content using chromatography method.

Methods: Six complementary test systems, namely, 1,1-diphenyl 2-picryl hydrazine (DPPH), hydrogen peroxide ( $\mathrm{H}_{2} \mathrm{O}_{2}$ ), superoxide ( $\mathrm{SO}$ ), nitric oxide (NO), hydroxyl $(\mathrm{OH})$ radical scavenging, and reducing power activities were analyzed for determining antioxidant activity of EPGL. The simple and novel chromatography techniques such as thin-layer chromatography (TLC) and high-performance liquid chromatography (HPLC) were used for the detection and quantification of GA in EPGL.
\end{abstract}

Results: $\mathrm{IC}_{50}$ values of EPGL were found to be $136 \mu \mathrm{g} / \mathrm{ml}$ for DPPH, $88.5 \mu \mathrm{g} / \mathrm{ml}$ for $\mathrm{H}_{2} \mathrm{O}_{2}, 16.8 \mu \mathrm{g} / \mathrm{ml}$ for SO, $96.5 \mu \mathrm{g} / \mathrm{ml}$ for $\mathrm{NO}$, and $143 \mu \mathrm{g} / \mathrm{ml}$ for $0 \mathrm{H}$. The ascorbic acid (AA) and GA were used as standard compounds. The absorbance of EPGL in reducing power assay was found to be 0.18 at $100 \mu \mathrm{g} /$ $\mathrm{ml}$, while AA and GA absorbance was found to be 0.24 and 0.4 at the same concentration. The amount of GA in EPGL was found to be 1.189 mg/g.

Conclusion: These findings suggested that EPGL could be a potential source of natural antioxidant, and HPLC method used for the determination of GA is simple, precise, accurate, and suitable for routine analysis of GA in EPGL.

Keywords: Punica granatum, Free radical scavenging, Oxidative stress, Chromatography techniques, Gallic acid.

(C) 2018 The Authors. Published by Innovare Academic Sciences Pvt Ltd. This is an open access article under the CC BY license (http://creativecommons. org/licenses/by/4. 0/) DOI: http://dx.doi.org/10.22159/ajpcr.2018.v11i4.24378

\section{INTRODUCTION}

Free radicals are molecules containing one or more unpaired electrons in atomic or molecular orbitals. There is increasing evidence that the abnormal production of free radicals leads to increased oxidative stress on cellular structures which causes a change in molecular pathways that pave the pathogenesis of several important diseases such as cardiovascular diseases, neurological diseases, and cancer and in the process of physiological aging [1]. All human cells protect themselves against free radical damage by enzymes such as superoxide dismutase and catalase or compounds such as ascorbic acid (AA), tocopherols, and glutathione [2]. Sometimes, these mechanisms are disrupted by various pathological processes, and therefore, antioxidant supplements are vital to combat oxidative damage. In recent years, natural antioxidants, particularly, those present in fruits and vegetables have gained increasing interest among consumers and in the scientific community. Epidemiological studies have demonstrated that frequent intake of fruits and vegetables is associated with a lower risk of age-related diseases such as coronary heart diseases and cancer $[3,4]$. Recently, much attention has been directed toward the development of ethnomedicines with strong antioxidant properties but low cytotoxicity. One important aspect of the quality control of herbal medicinal products is the determination of the chemical marker, which consists of a constituent (or groups of constituents) that is chemically defined and present in the plant product. These constituents may or may not be related to their pharmacological activity [5]. While several different analytical techniques can be used to identify and quantify these substances, we used high-performance liquid chromatography (HPLC), which is the most commonly used method [6].

Punica granatum L., commonly known as pomegranate, is a fruitbearing deciduous shrub or small tree, native to Asia, and belongs to the family Lythraceae [7]. Different parts of the plant such as bark, leaves, immature fruits, and fruit rind have medicinal significance [8]. P. granatum has been extensively used as a traditional medicine in many countries for the treatment of dysentery, diarrhea, helminthiasis, acidosis, hemorrhage, and respiratory pathologies [9]. In addition, this plant is reported to have excellent antibacterial, antifungal, and antiprotozoal activity [10-12].

We have reported the phytochemical content of $P$ granatum leaf extract [13]. Therefore, the present study was undertaken with the objectives to assess the antioxidant potential of the ethanolic extract of $P$. granatum L. Leaf (EPGL) using different standard methods and to develop and validate an analytical method using thin-layer chromatography (TLC) and high performance liquid chromatography for the identification and quantification of the chemical marker, namely, gallic acid (GA) in EPGL.

\section{METHODS}

\section{Collection and identification of plant materials}

P. granatum (Punicaceae) leaves were collected on August 2016 from around the Sathyavedu village, Andhra Pradesh, India, and was identified by Dr. P. Jayaraman, Director of National Institute of Herbal science, Plant anatomy research center, Chennai (PARC/2017/3381).

\section{Preparation of leaf extracts}

The leaf samples were shade dried at room temperature and then ground to a fine powder in a mechanical grinder. The powdered material was then extracted using a solvent ethanol in the ratio 1:10 using Soxhlet apparatus. After extracting all coloring material, the solvent was removed by evaporating in a water bath, which gives rise to a solid mass of the extract. The percentage yield of the extract was found to be $12 \%$.

\section{Chemicals}

GA was purchased from Sigma-Aldrich (Chennai, India). HPLC grade water, methanol, acetonitrile, and orthophosphoric acid from Merck Specialities Private Ltd. (Mumbai) were used in this study. All other chemicals and reagents used were commercially available purity. 
Preparation of standards

In vitro antioxidant activity of ethanolic extract of $P$. granatum Leaf (EPGL) was studied by comparing with the standards - AA and GA. A stock solution of AA and GA was prepared at a concentration of $1 \mathrm{mg} / \mathrm{ml}$. From the stock solution, required concentrations of AA and GA were prepared.

\section{Statistical analysis}

Data were expressed as mean \pm standard deviation for three parallel measurements. The $50 \%$ inhibitory concentration $\left(\mathrm{IC}_{50}\right.$ ) was calculated from the dose-response curve (Graph Pad Prism Version 6.0) by plotting the percentage of inhibition versus concentrations.

Percentage of inhibition=Absorbance of control-Absorbance of test sample $\div$ Absorbance of control $\times 100$

The $\mathrm{IC}_{50}$ value is defined as the concentration $(\mu \mathrm{g} / \mathrm{ml})$ of dry extract that inhibits the formation of free radicals by $50 \%$.

\section{1,1-diphenyl 2-picryl hydrazine (DPPH) radical scavenging assay} Method of Singh et al. [14] was adopted for the determination of DPPH free radical scavenging activity. DPPH (7.886 mg) was accurately weighed and dissolved in $100 \mathrm{ml}$ of methanol to obtain $200 \mu \mathrm{mol}$ solutions of DPPH. EPGL was prepared with five concentrations, namely, $50,100,150,200$, and $250 \mu \mathrm{g} / \mathrm{ml}$. $2 \mathrm{ml}$ of methanol solution of DPPH shaken vigorously with $2 \mathrm{ml}$ of sample solution and allowed to stand at room temperature for $15 \mathrm{~min}$ in the dark. The absorbance of the reaction mixture was measured spectrophotometrically at $517 \mathrm{~nm}$. Different concentrations of AA and GA $(20,40,50,80$, and $100 \mu \mathrm{g} / \mathrm{ml})$ were used as reference compounds. The percentage of DPPH scavenging of both the EPGL and standard compounds (AA and GA) was calculated.

\section{Hydrogen peroxide radical $\left(\mathrm{H}_{2} \mathrm{O}_{2}\right)$ scavenging assay}

$\mathrm{H}_{2} \mathrm{O}_{2}$ scavenging ability of EPGL was determined according to the method of Ebrahimzadeh et al. [15]. Standard AA and GA were prepared at concentrations of $20,40,50,80$, and $100 \mu \mathrm{g} / \mathrm{ml}$, whereas EPGL was prepared at concentrations of 50,100, 150, 200, and $250 \mu \mathrm{g} / \mathrm{ml}$. A solution of $\mathrm{H}_{2} \mathrm{O}_{2}$ (40 millimol) was prepared in phosphate buffer ( $\mathrm{pH}$ 7.4). To $1 \mathrm{ml}$ of standards and $1 \mathrm{ml}$ of EPGL solution at various concentrations, $3.4 \mathrm{ml}$ of phosphate buffer and $0.6 \mathrm{ml}$ of $\mathrm{H}_{2} \mathrm{O}_{2}$ were added. The absorbance of $\mathrm{H}_{2} \mathrm{O}_{2}$ at $230 \mathrm{~nm}$ was determined after $10 \mathrm{~min}$ against the blank solution containing the phosphate buffer without $\mathrm{H}_{2} \mathrm{O}_{2} .1 \mathrm{ml}$ of phosphate buffer and $0.6 \mathrm{ml}$ of $\mathrm{H}_{2} \mathrm{O}_{2}$ were used as a control. Reactions were carried out in triplicate spectrophotometrically. The percentage of $\mathrm{H}_{2} \mathrm{O}_{2}$ scavenging of both the EPGL and standard compounds (AA and GA) was calculated.

\section{Superoxide (SO) radical scavenging assay}

The SO radical scavenging activity of the EPGL was studied using the method of Liu et al.[16]. SO radicals are generated in phenazine methosulfate-reduced nicotinamide adenine dinucleotide (PMSNADH) systems by oxidation of NADH and assayed by the reduction of nitro blue tetrazolium (NBT). About $200 \mu \mathrm{l}$ of EPGL at different concentrations were taken in a series of test tubes. SO radicals were generated by $1 \mathrm{ml}$ of Tris-hydrochloride (Tris-HCl) buffer (16 millimol, $\mathrm{pH}-8), 1 \mathrm{ml}$ of NBT (50 $\mu \mathrm{mol}), 1 \mathrm{ml}$ of NADH $(78 \mu \mathrm{mol})$ solution, and $1 \mathrm{ml}$ of PMS $(10 \mu \mathrm{mol})$. The reaction mixture was incubated at $25^{\circ} \mathrm{C}$ for $5 \mathrm{~min}$ and the absorbance was measured at $560 \mathrm{~nm}$. A control tube containing Tris- $\mathrm{HCl}$ buffer was also processed in the same way without EPGL and standards. Different concentrations of AA and GA were used as reference compounds. The inhibition percentage of SO anion generation was calculated.

\section{Nitric oxide (NO) radical scavenging assay}

NO radical scavenging activity was measured spectrophotometrically according to the method described by Govindharajan et al.[17]. When sodium nitroprusside was mixed with an aqueous solution at physiological $\mathrm{pH}$, suddenly it generates NO, which reacts with oxygen to produce nitrite ions that can be estimated using Griess reagent. NO scavengers compete with oxygen, which leads to reduced production of nitrite ions. About $1 \mathrm{ml}$ of sodium nitroprusside (5 millimol) in phosphate buffer ( $\mathrm{pH} 7.4,0.1 \mathrm{~mol})$ was mixed with different concentrations $(50,100,150,200$, and $250 \mu \mathrm{g} / \mathrm{ml})$ of the EPGL in

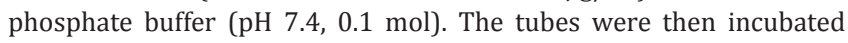
at $25^{\circ} \mathrm{C}$ for $2 \mathrm{~h}$. After incubation, $1.5 \mathrm{ml}$ of the reaction mixture was taken and diluted with $1.5 \mathrm{ml}$ of Griess reagent $1 \%$ sulfanilamide, $2 \% 0$-phosphoric acid, and $0.1 \%$ of $\mathrm{N}$-[1- naphthyl ethylenediamine dihydrochloride]). The absorbance of the chromophore formed during diazotization of the nitrite with sulfanilamide and subsequent coupling with N-(1- naphthyl ethylenediamine dihydrochloride) was measured spectrophotometrically at $546 \mathrm{~nm}$. Control tube was maintained with all chemicals excluding EPGL and standards. The AA and GA were used as reference standards. The percentage inhibition of NO anion generation was calculated.

\section{Hydroxyl $(\mathrm{OH})$ radical scavenging assay}

The $\mathrm{OH}$ radical scavenging activity of EPGL was measured according to the method of Halliwell et al.[18]. Stock solutions of ethylenediaminetetraacetic acid (EDTA) (1 millimol) were prepared in dimethyl sulfoxide, whereas ferric chloride $\left(\mathrm{FeCl}_{3}\right)$ (10 millimol), AA (1 millimol), $\mathrm{H}_{2} \mathrm{O}_{2}$ (10 millimol), and deoxyribose (10 millimol) were prepared in deionized water. The method was carried out by adding $100 \mu \mathrm{l}$ of EDTA, $10 \mu \mathrm{l}$ of $\mathrm{FeCl}_{3}, 100 \mu \mathrm{l}$ of $\mathrm{H}_{2} \mathrm{O}_{2}, 360 \mu \mathrm{l}$ of deoxyribose, $1000 \mu \mathrm{l}$ of the EPGL $(50-250 \mu \mathrm{g} / \mathrm{ml}), 330 \mu \mathrm{l}$ of phosphate buffer $(50$ millimol, $\mathrm{pH} 7.4$ ), and $100 \mu \mathrm{l}$ of AA. This mixture was then incubated at $37^{\circ} \mathrm{C}$ for $1 \mathrm{~h}$. About $1 \mathrm{ml}$ of incubated mixture was mixed with $1 \mathrm{ml}$ of $10 \%$ trichloroacetic acid (TCA) and $1 \mathrm{ml}$ of $0.5 \%$ thiobarbituric acid (TBA) (in 0.025 mol sodium hydroxide containing $0.025 \%$ butylated $\mathrm{OH}$ anisole), and the development of pink chromogen was measured spectrophotometrically at $532 \mathrm{~nm}$. The AA and GA were used as standards. The inhibition percentage of $\mathrm{OH}$ anion was calculated.

\section{Reducing power assay method}

The reducing power ofEPGL was determined by the method of Oyaizu [19]. Different concentrations of EPGL $(50,100,150,200$, and $250 \mu \mathrm{g} / \mathrm{ml})$ and standards $(20,40,50,80$, and $100 \mu \mathrm{g} / \mathrm{ml})$ were prepared, and $1 \mathrm{ml}$ of each solution was mixed with $2.5 \mathrm{ml}$ of phosphate buffer $(0.2 \mathrm{~mol}$, $\mathrm{pH} 6.8$ ) and $2.5 \mathrm{ml}$ of $1 \%$ potassium ferricyanide. The mixture was incubated at $50^{\circ} \mathrm{C}$ for $20 \mathrm{~min}$. To this mixture, $2.5 \mathrm{ml}$ of $10 \%$ TCA was added and then centrifuged at 3000 rotation per minute for $10 \mathrm{~min}$. The upper layer of the solution $(2.5 \mathrm{ml})$ was mixed with distilled water ( $2.5 \mathrm{ml}$ ) and $0.1 \% \mathrm{FeCl}_{3}(0.5 \mathrm{ml})$, and the absorbance was measured at $700 \mathrm{~nm}$. The AA and GA were used as standards.

\section{TLC and HPLC Profiling of PGLE \\ TLC}

Chromatography was performed as described by Marston et al.[20] on $10 \times 10 \mathrm{~cm}$ precoated silica gel 60F $254 \mathrm{TLC}$ plate and $5 \mu \mathrm{l}$ of standard and test solution (concentration $1 \mathrm{mg} / \mathrm{ml}$ ) at $25 \mathrm{~mm}$ distance to the TLC plate was applied. Thereafter, the plate was developed using optimized solvent system chloroform, methanol, and formic acid (FA) (7:2:1) as mobile phase in a glass chamber which was previously saturated for $10 \mathrm{~min}$. The plate was developed up to $8 \mathrm{~cm}$ and development time was $50 \mathrm{~min}$. Then, the developed plate was dried at $60^{\circ} \mathrm{C}$ for $15 \mathrm{~min}$ and sprayed with $1 \%$ methanolic $\mathrm{FeCl}_{3}$ reagent. Identification of GA in EPGL and comparison of retardation factor value with the standard were noted.

\section{HPLC}

Quantification of GA was carried out using Shimadzu 20 AD, HPLC system (Shimadzu, Japan) consisted of ultraviolet (UV) detector, a binary pump, a $20 \mu$ injection loop, and a RP-18 column of dimensions $4.6 \times 250 \mathrm{~mm}$. The mobile phase used for GA was water $(80 \%)$ and acetonitrile $(20 \%)$ with $\mathrm{pH}$ is maintained at 3.0 using 0 -phosphoric acid at a flow rate of $1.0 \mathrm{ml} / \mathrm{min}$. The eluted samples were detected by UV detector at $272 \mathrm{~nm}$. Stock solutions of standard GA and EPGL were prepared in methanol as $50 \mu \mathrm{g} / \mathrm{ml}$ and $1 \mathrm{mg} / \mathrm{ml}$, respectively. EPGL and GA as well as the mobile phase were degassed and filtered through a membrane filter (0.45 millipore). The amount of GA in EPGL was determined by comparing the retention time with the standard GA [21]. 


\section{RESULTS AND DISCUSSIONS}

In living systems, free radicals are constantly generated and they can cause extensive damage to tissues and biomolecules leading to various disease conditions, especially degenerative diseases and extensive lysis [22]. Many synthetic drugs protect against oxidative damage, but they have diverse side effects. An alternative solution to the problem is to consume natural antioxidants from food supplements and traditional medicines [23]. Plants rich in secondary metabolites, including phenols, flavonoids, and carotenoids, have antioxidant activity due to their redox properties and chemical structures [24,25].

\section{DPPH free radical scavenging activity}

The 1,1-diphenyl 2-picryl hydrazine (DPPH) scavenging ability of EPGL was $14.8 \pm 0.4$ to $77.7 \pm 0.4 \%$ at concentrations of $50-250 \mu \mathrm{g} / \mathrm{ml}$. The scavenging activity of AA and GA was $36.2 \pm 2$ to $86.9 \pm 0.8 \%$ and $29.6 \pm 0.25$ to $75.86 \pm 0.25 \%$ at concentrations of $20-100 \mu \mathrm{g} / \mathrm{ml}$ which were used as reference compounds. Fig. 1 shows the dose-dependent DPPH scavenging activity of EPGL, AA, and GA with an $\mathrm{IC}_{50}$ value of $136 \mu \mathrm{g} / \mathrm{ml}, 30.5 \mu \mathrm{g} / \mathrm{ml}$, and $38.5 \mu \mathrm{g} / \mathrm{ml}$. Our results $\left(\mathrm{IC}_{50}=136 \mu \mathrm{g} / \mathrm{ml}\right)$ were similar to the reports given by Zhang et al. $\left(\mathrm{IC}_{50}=0.14 \mathrm{mg} / \mathrm{ml}\right.$ ) and Gheith and El-Mahmoudy ( $\mathrm{IC}_{50}=113 \mu \mathrm{g} / \mathrm{ml}$ ) [26,27]. DPPH is usually used as a reagent to evaluate free radical and accepts an electron or hydrogen to become a stable diamagnetic molecule [28]. The decrease in absorbance of DPPH radical scavenging caused by antioxidant was due to the scavenging of the radical by hydrogen donation. It is visually noticeable as a color change from purple to yellow.

\section{$\mathrm{H}_{2} \mathrm{O}_{2}$ scavenging assay}

The ability of the EPGL to scavenge $\mathrm{H}_{2} \mathrm{O}_{2}$ is shown in Fig. 2 and compared with that of $\mathrm{AA}$ and $\mathrm{GA}$ as reference compounds. The $\mathrm{IC}_{50}$ value of the EPGL $(88.5 \mu \mathrm{g} / \mathrm{ml})$ was more than that of the reference compounds, AA $(16.5 \mu \mathrm{g} / \mathrm{ml})$ and GA $(42.5 \mu \mathrm{g} / \mathrm{ml})$. At $250 \mu \mathrm{g} /$

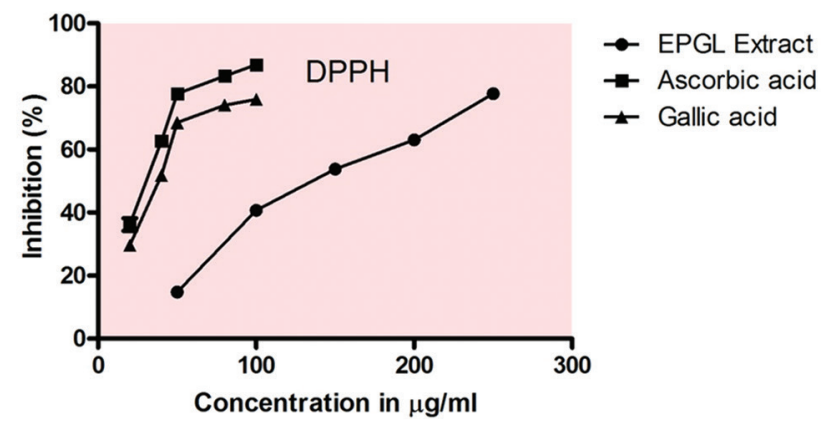

Fig. 1: 1,1-diphenyl -2-picrylhydrazyl radical scavenging activity of ethanolic extracts of Punica granatum Leaf, ascorbic acid, and gallic acid. The values are expressed in mean \pm standard deviation $(n=3)$

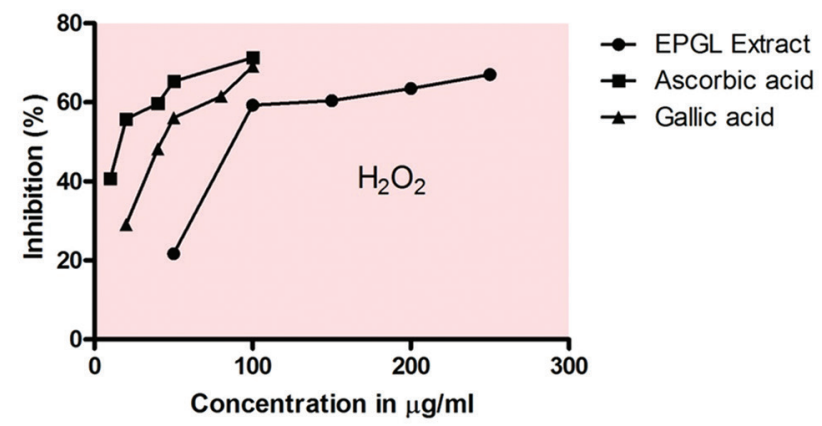

Fig. 2: Hydrogen peroxide scavenging activity of ethanolic extracts of Punica granatum Leaf ascorbic acid, and gallic acid. The values are expressed in mean \pm standard deviation $(n=3)$ ml, EPGL showed $67 \pm 0.2 \%$ of inhibition, whereas Vinodhini et al. reported methanolic extract of PGL $55.25 \%$ of inhibition at the same concentration [29]. Biological systems can produce $\mathrm{H}_{2} \mathrm{O}_{2} \cdot \mathrm{H}_{2} \mathrm{O}_{2}$ can be formed in vivo by several oxidizing enzymes such as SOD. It can cross membranes and may slowly oxidize a number of compounds. It is used in the respiratory burst of activated phagocytes [30]. It is therefore biologically advantageous for cells to control the amount of $\mathrm{H}_{2} \mathrm{O}_{2}$ that is allowed to accumulate. The ability of EPGL to scavenge $\mathrm{H}_{2} \mathrm{O}_{2}$ may be attributed to the presence of phenols and tannins, which could donate electrons, thereby neutralizing it into water.

\section{So radical scavenging activity}

The SO scavenging activity of EPGL $\left(\mathrm{IC}_{50}-16.8 \mu \mathrm{g} / \mathrm{ml}\right)$ was more than AA $\left(\mathrm{IC}_{50}-23.8 \mu \mathrm{g} / \mathrm{ml}\right)$ but less than $\mathrm{GA}\left(\mathrm{IC}_{50}-3.25 \mu \mathrm{g} / \mathrm{ml}\right)$. However, Rummun et al. proposed $\mathrm{IC}_{50}$ value of methanolic extract of $P$. granatum leaves as $0.072 \pm 0.001 \mathrm{mg} / \mathrm{ml}$ which is more than we value [31] The EPGL at a concentration of $5 \mu \mathrm{g} / \mathrm{ml}$ showed $17.7 \%$, whereas in $100 \mu \mathrm{g} / \mathrm{ml}$ concentration, the percentage of inhibition was recorded as $86.7 \%$ (Fig. 3). This clearly indicates the inhibition activity was dose dependent. SO anion plays an important role in the formation of other reactive oxygen species such as $\mathrm{H}_{2} \mathrm{O}_{2}$, OH radical $(\mathrm{OH})$, and singlet oxygen, which induce oxidative damage in lipids, proteins, and deoxyribonucleic acid [32]. It has been reported that antioxidant properties of some flavonoids are effective mainly through scavenging of the SO anion radical [33]. As shown in Fig. 3, the decrease in absorbance by antioxidants indicates consumption of SO anion in the reaction mixture. The results suggested that the EPGL is a more potent scavenger of SO radical than the standard AA but less than GA.

\section{NO scavenging activity}

The NO scavenging activity of the EPGL was $31.5 \pm 3 \%$ of the minimum concentration of $50 \mu \mathrm{g} / \mathrm{ml}$, whereas maximum activity was $75.6 \pm 1.5 \%$ at $250 \mu \mathrm{g} / \mathrm{ml}$. Our IC I0 $_{50}$ value $(96.5 \mu \mathrm{g} / \mathrm{ml})$ of EPGL was in near agreement with $\mathrm{IC}_{50}$ values $(55.65 \pm 0.72 \mu \mathrm{g} / \mathrm{ml})$ given by Hossain et al. [34], whereas $\mathrm{IC}_{50}$ values of AA and GA were $29.5 \mu \mathrm{g} / \mathrm{ml}$ and $5.5 \mu \mathrm{g} / \mathrm{ml}$, respectively. Fig. 4 shows that the percentage of inhibition was increased with increasing concentration of the EPGL. However, the activity of AA and GA was more pronounced than that of the EPGL. In vitro inhibition of NO (NO) radical is a measure of antioxidant activity of plant drugs. NO plays an important role in various inflammatory processes, but the overproduction of NO contributes to various diseases. The toxicity of NO increases greatly when it reacts with SO radical, forming the highly reactive peroxynitrite anion [35]. EPGL effectively reduced the generation of NO from sodium nitroprusside. The degree of inhibition of the NO free radicals was found to be increased with increasing concentrations of the EPGL extracts, and this indicates that the EPGL may contain compounds capable of inhibiting the generation of $\mathrm{NO}$ and offers scientific evidence for the use of EPGL in the treatment of various diseases.

\section{$\mathrm{OH}$ radical scavenging activity}

Fig. 5 showed the abilities of the EPGL and standards (AA and GA) to inhibit $\mathrm{OH}$ radical-mediated deoxyribose degradation of ferric

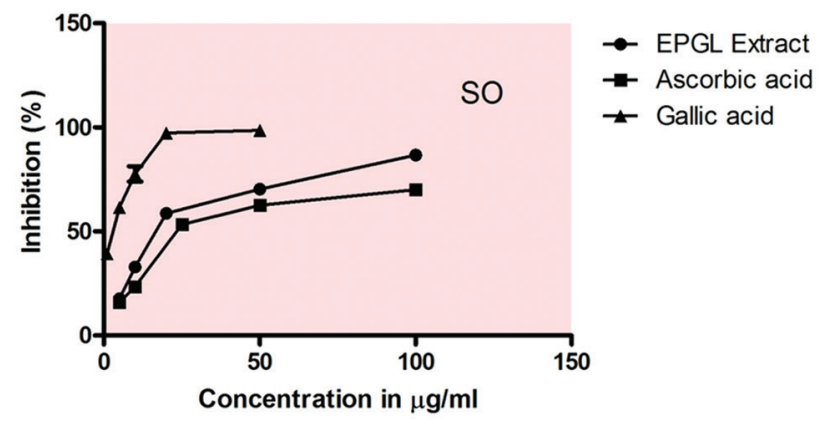

Fig. 3: Superoxide scavenging activity of ethanolic extracts of Punica granatum Leaf, ascorbic acid, and gallic acid. The values are expressed in mean \pm standard deviation $(n=3)$ 
$\left(\mathrm{Fe}^{3+}\right)$-EDTA - AA and $\mathrm{H}_{2} \mathrm{O}_{2}$ reaction mixture. The $\mathrm{IC}_{50}$ values of the EPGL, AA, and GA in this assay were $143 \mu \mathrm{g} / \mathrm{ml}, 32.5 \mu \mathrm{g} / \mathrm{ml}$, and $8.5 \mu \mathrm{g} / \mathrm{ml}$, respectively. However, Gheith and Mahmoudy reported $\mathrm{IC}_{50}$ of hydromethanolic extract of PGL as $79.67 \pm 0.03 \mu \mathrm{g} / \mathrm{ml}$ [27]. At $100 \mu \mathrm{g} / \mathrm{ml}$, the inhibition percentage values were $33.6 \%, 78.6 \%$, and $99.2 \%$ for EPGL, AA, and GA, respectively. The OH radical is regarded as a detrimental species in pathophysiological processes and capable of damaging any molecule of the biological system and thus contributes to carcinogenesis, mutagenesis, and cytotoxicity [36]. As mentioned in the methods section, $\mathrm{OH}$ radicals were produced by incubating ferricEDTA with AA and $\mathrm{H}_{2} \mathrm{O}_{2}$ at $\mathrm{pH} 7.4$ and reacted with 2-deoxy-2-ribose to generate a malondialdehyde (MDA) like product. This compound forms a pink chromogen on heating with TBA at low $\mathrm{pH}$. When EPGL was added to the reaction mixture, it removed the $\mathrm{OH}$ radicals from the sugar and prevented the reaction. $\mathrm{The}_{\mathrm{IC}}$ indicates that the plant extract has good $\mathrm{OH}$ radical scavenging ability, but lesser than the standard AA and GA.

\section{Reducing power assay}

An increase in absorbance indicates an increase in the antioxidant activity. The EPGL showed increased absorbance as the concentration increased. At $100 \mu \mathrm{g} / \mathrm{ml}$, EPGL showed 0.18 absorbance, while AA and GA showed 0.24 and 0.4 absorbance at the same concentration (Table 1 ).

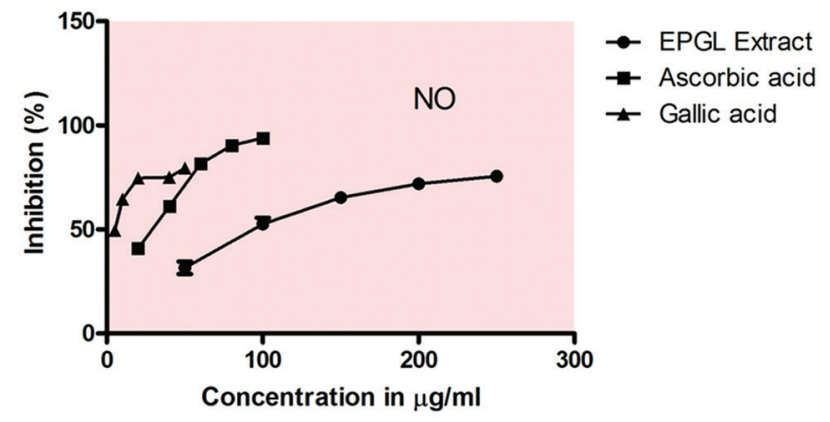

Fig. 4: Nitric oxide activity of ethanolic extracts of Punica granatum Leaf, ascorbic acid, and gallic acid. The values are expressed in mean \pm standard deviation $(n=3)$

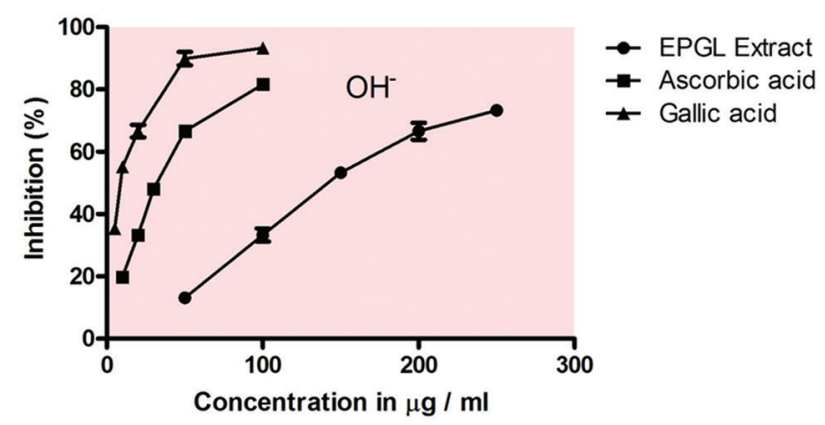

Fig. 5: Hydroxyl radical scavenging activity of ethanolic extracts of Punica granatum Leaf, ascorbic acid, and gallic acid. The values are expressed in mean \pm standard deviation $(n=3)$.
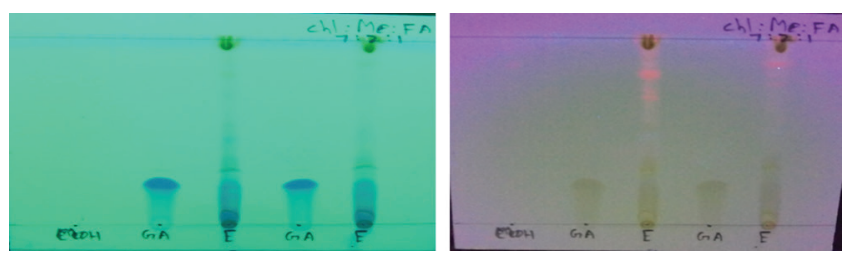

Fig. 6: Thin-layer chromatography of gallic acid and ethanolic extract of Punica granatum Leaf in short ultraviolet (UV)

(254 $\mathrm{nm}$ ) and long UV (365 $\mathrm{m})$, respectively, with the mobile phase composition chloroform:methanol:Formic acid $=7: 2: 1$
However, Hossain et al. proposed that EPGL showed 2.015 \pm 0.09 absorbance at $100 \mu \mathrm{g} / \mathrm{ml}$ which was much more than our absorbance [34]. Compounds by reducing power can reduce the oxidized intermediates of lipid peroxidation processes so that they can act as primary and secondary antioxidants [37]. In the reducing power assay, the presence of antioxidants in the samples would result in the reduction of ferric $\left(\mathrm{Fe}^{+}\right)$to ferrous $\left(\mathrm{Fe}^{2+}\right)$ by donating an electron. Amount of $\mathrm{Fe}^{2+}$ complex can be monitored by measuring the formation of Prussian blue at $700 \mathrm{~nm}$ indicating an increase in reducing power [38]. Therefore, by measuring the formation of Perl's Prussian Blue at $700 \mathrm{~nm}$, we can monitor the $\mathrm{Fe}^{2+}$ concentration. A high absorbance value of the sample indicates its strong antioxidant activity [39]. In the present study, the reducing power of EPGL was found to be excellent and steadily increased in direct proportion to the increasing concentrations of the EPGL.

From the above observation, we concluded that, except DPPH scavenging activity, other antioxidant activities of EPGL showed the difference when compared to other works. This difference may be due to the method and solvent adopted for extraction and in addition harvest time.

\section{TLC and HPLC analysis}

The result of TLC analysis using chloroform, methanol, and FA solvent mixture confirmed the presence of GA in EPGL (Fig. 6). The HPLC analysis of EPGL showed the presence of GA and other important peaks of phenols and flavonoids, which are reported to have antioxidant activity and these findings, are in concordance with our results. Quantitative HPLC studies show that the EPGL contained GA $(1.189 \mathrm{mg} / \mathrm{g})$ in good quantity with retention time in minute (Rt value) recorded was compared to standard GA (Figs. 7 and 8). The precision as well as the reproducibility of this method was satisfactory.

\section{CONCLUSION}

Nowadays, our knowledge about the role played by the free radicals in metabolic diseases such as diabetes, liver disease, and hypertension is significantly increased. The present study indicates that the EPGL possesses antioxidant properties and could serve as free radical inhibitor or scavenger or act as primary antioxidant. By measuring the antioxidant activity, we noticed that EPGL exhibited very high SO scavenging activity reaching over $86.7 \%$ at $100 \mu \mathrm{g} / \mathrm{ml}$. The findings of the present study suggested that EPGL is a potential source of natural antioxidant that could have great importance as therapeutic agent in preventing or slowing the progress of aging and age-associated oxidative stress-related

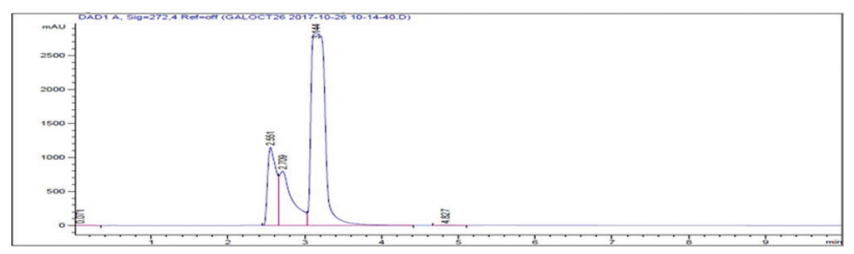

Fig. 7: Chromatogram of gallic acid was analyzed using highperformance chromatography with mobile phase composition 80\%water: $20 \%$ acetonitrile at $\mathrm{pH} 3$

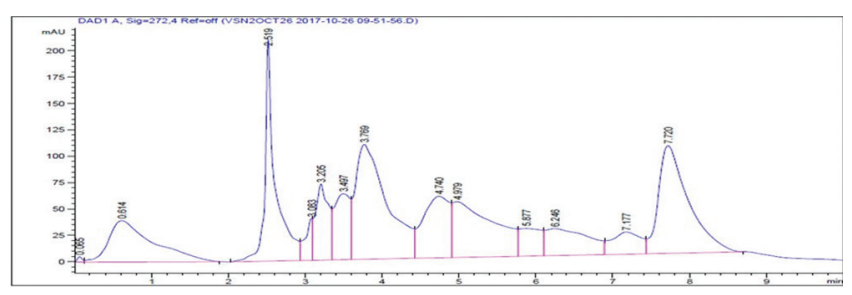

Fig. 8: Chromatogram of ethanolic extract of Punica granatum Leaf $L$. was analyzed using high-performance liquid chromatography with mobile phase composition $80 \%$ water: $20 \%$ acetonitrile at $\mathrm{pH} 3$. 
Table 1: Reducing power of EPGL, AA, and GA

\begin{tabular}{llllll}
\hline EPGL & Concentration in $\mu \mathrm{g} / \mathrm{ml}$ & 50 & 100 & 150 & 200 \\
& Absorbance at $700 \mathrm{~nm}$ & $0.09 \pm 0.01$ & $0.18 \pm 0.015$ & $0.24 \pm 0.005$ & $0.29 \pm 0.02$ \\
AA & Concentration in $\mu \mathrm{g} / \mathrm{ml}$ & 20 & 40 & 50 & $0.33 \pm 0.01$ \\
GA & Absorbance at $700 \mathrm{~nm}$ & $0.06 \pm 0.005$ & $0.13 \pm 0.01$ & $0.20 \pm 0.01$ & $0.21 \pm 0.01$ \\
\hline
\end{tabular}

Values are expressed in mean \pm standard deviation ( $\mathrm{n}=3$ ). EPGL: Ethanolic extract of Punica granatum Leaf, AA: Ascorbic acid, GA: Gallic acid

Table 2: Chromatography result of GA and EPGL

\begin{tabular}{lll}
\hline Parameter & GA & EPGL \\
\hline Retention time (min) & 3.14 & 3.205 \\
Peak area & 35949.5 & 854.9606 \\
Area (\%) & 65.96 & 6.5756 \\
Response factor (mAU*S) & 718.99 & 1.10535 \\
Amount of GA in EPGL=1.189 mg/g of extract & \\
\hline
\end{tabular}

EPGL: Ethanolic extract of Punica granatum Leaf, GA: Gallic acid, min: Minutes, mAU*s: Milli absorbance units per second.

degenerative diseases. Further, a simple, accurate, and reliable method was developed to determine the GA content in EPGL using HPLC. Thus, it is suitable for the quantification of GA in herbal medicine.

\section{AUTHORS CONTRIBUTION}

Mrs. P. Sreedevi (Research Scholar) carried out the experiments and has written manuscript. Dr. K. Vijayalakshmi (Principal Investigator) designed the work, proofread and validated the manuscript.

\section{CONFLICT OF INTEREST}

Declared None.

\section{REFERENCES}

1. Cheng HY, Lin TC, Yu KH, Yang CM, Lin CC. Antioxidant and free radical scavenging activities of Terminalia chebula. Biol Pharm Bull 2003;26:1331-5.

2. Niki E, Shimaski H, Mino H. Antioxidantism-Free Radical and Biological Defense. Tokyo: Gakkai Syuppn Centre; 1994.

3. Temple NJ. Antioxidants and disease: More questions than answers. Nutr Res 2000;20:449-9.

4. La Vecchia C, Altieri A, Tavani A. Vegetables, fruit, antioxidants and cancer: A review of Italian studies. Eur J Nutr 2001;40:261-7.

5. Marques GS, Leao WF, Lyra MA, Peixoto MS, Monteiro RP, Rolim LA, et al. Comparative evaluation of UV/VIS and HPLC analytical methodologies applied for quantification of flavonoids from leaves of Bauhinia forficata. Rev Bras Farmacogn 2012;23:51-7.

6. Zollner T, Schwarz M. Herbal reference standards: Applications, definitions and regulatory requirements. Rev Bras Farmacogn 2013;23:1-21.

7. Altuner EM. Investigation of antimicrobial activity of Punica granatum L. fruit peel ash used for protection against skin infections as folk remedies especially after male circumcision. Afr J Microbiol Res 2011;5:3339-2.

8. Arun N, Singh DP. Punica granatum: A review on pharmacological and therapeutic properties. Int J Pharm Sci Res 2012;3:1240-5.

9. Choi JG, Kang OH, Lee YS, Chae HS, Oh YC, Brice OO, et al. In vitro and in vivo antibacterial activity of Punica granatum peel ethanol extract against salmonella. Evid Based Complement Alternat Med 2009;2011:1-8.

10. Dahham SS, Ali MN, Tabassum H, Khan M. Studies on antibacterial and antifungal activity of pomegranate (Punica granatum L.). Am Eur J Agric Environ Sci 2010;9:273-1.

11. Inabo HI, Fathuddin MM. In vivo antitrypanosomal potentials of ethyl acetate leaf extracts of Punica granatum against Trypanosoma brucei brucei. Adv Agr Biol 2011;1:82-8.

12. Moussa AM, Emam AM, Diab YM, Mahmoud ME, Mahmoud AS. Evaluation of antioxidant potential of 124 Egyptian plants with emphasis on the action of Punica granatum leaf extract on rats. Int Food Res J 2011;18:535-2.

13. Sreedevi P, Vijayalakshmi K, Venkataeswari R. Phytochemical evaluation of Punica granatum L. Leaf extract. Int J Curr Pharm Res 2017;9:14-8.

14. Singh RP, Murthy KN, Jayaprakasha GK. Studies on the antioxidant activity of pomegranate (Punica granatum) peel and seed extracts using in vitro models. J Agric Food Chem 2002;50:81-6.

15. Ebrahimzadeh MA, Nabavi SF, Nabavi SM. Antioxidant activity of leaves and inflorescence of Eryngium caucasicum Trautv at flowering stage. Phcog Res 2009;1:435-9.

16. Liu F, Ooi VE, Chang ST. Free radical scavenging activites of mushroom polysaccharide extracts. Life Sci 1997;60:763-1.

17. Govindharajan R, Rastogi S, Vijayakumar M, Rawat AK, Shirwaikar A, Mehrotra S, et al. Studies on the antioxidant activities of Desmodium gangeticum. Biol Pharm Bull 2003;26:1424-7.

18. Halliwell B, Gutteridge JM, Cross CE. Free radicals, antioxidants, and human disease: Where are we now? J Lab Clin Med 1992;119:598-20.

19. Oyaizu M. Studies on products of browning reaction-antioxdative activities of products of browning reaction prepared from glucoseamine. Jpn J Nutr Diet 1986;44:307-5.

20. MarstonA, Kissling J, Hostettmann K. A rapid TLC bioautographic method for the detection of acetylcholineesterase and butyrylcholineesterase inhibitors in plants. Phytochem Anal 2002;13:51-4.

21. Kardani K, Gurav N, Solanki B, Patel P, Patel B. RP-HPLC method development and validation of gallic acid in polyherbal tablet formulation. J Appl Pharm Sci 2013;3:37-2

22. Halliwell B, Gutteridge JM. Free Radicals in Biology and Medicine. UK: Oxford University Press; 1998.

23. Yazdanparast R, Ardestani A. In vitro antioxidant and free radical scavenging activity of Cyperus rotundus. J Med Food 2007;10:667-4.

24. Schimoi K, Masuda S, Shen B, Furugori M, Kinae N. Radioprotective effects of antioxidative plant flavonoids in mice. Mutat Res 1996;350:153-61.

25. Sakat S, Juvekar AR, Gambhire MN. In-vitro antioxidant and antiinflammatory activity of methanol extract of Oxalis corniculata Linn. Int J Pharm Pharm Sci 2010;2:146-5.

26. Zhang LH, Li LL, Li YX, Zhang YH. In vitro antioxidant activities of fruits and leaves of Pomegranate. Acta Hortic 2008;765:31-4.

27. Gheith I, El-Mahmoudy A. Potent anti-oxidant and anti-inflammatory potentials of Punica granatum leaf and flower hydromethanolic extracts In vitro. Biosci J 2017;33:434-46.

28. Soares JR, Dins TC, Cunha AP, Almeida LM. Antioxidant activities of some extracts of Thymus Zygis. Free Radic Res 1997;26:469-8.

29. Vinodhini S, Shri Preethi M, Nusrath Fathima N, Kushwaha SS, Devi Rajeswari V. Antioxidant and free radical scavenging activity of Punica granatum leaf extracts. Asian J Pharm Clin Res 2016;9:17-20.

30. MacDonald-Wicks LK, Wood LG, Garg ML. Methodology for the determination of biological antioxidant capacity in vitro: A review. J Sci Food Agric 2006;86:2046-6.

31. Rummun N, Somanah J, Ramasaha S, Bahorun T, Neergheen-Bhujan SN. Bioactivity of nonedible parts of Punica granatum L.: A potential source of functional ingredients. Int J Food Sci 2013;2013:1-12.

32. Parejo I, Viladomat F, Bastida J, Rosas-Romero A, Flerlage N, Burillo J. et al. Comparison between the radical scavenging activity and antioxidant activity of six distilled and nondistilled mediterranean herbs and aromatic plants. J Agri Food Chem 2005;50:6882-90.

33. Yen G, Duh P. Scavenging effect of methanolic extracts of peanut hulls on free-radical and active-oxygen species. J Agri Food Chem 1994;42:629-2.

34. Hossain H, Ahmed T, Howlader MS, Dey SK, Hira A, Ahmed A, et al. In-vitro antioxidant potential from the leaves of Punica granatum Linn grown in Bangladesh. Int J Phytopharmcol Res 2012;2:160-6.

35. Huie RE, Padmaja S. The reaction of no with superoxide. Free Radic Res Commun 1993;18:195-9.

36. Babu BH, Shylesh BS, Padikkala J. Antioxidant and hepatoprotective effect of Acanthus ilicifolius. Fitoterapia 2001;72:272-7.

37. Ravishankar N, Sivaraj C, Seeni S, Joseph J, Raaman N. Antioxidant activities and phytochemical analysis of methanol extract of leaves of Hypericum Hookerianum. Int J Pharm Pharm Sci 2014;6:456-60.

38. Nabavi SM, Ebrahimzadeh MA, Nabavi SF, Fazelian M, Eslami B. In vitro antioxidant and free radical scavenging activity of Diospyros lotus and Pyrus boissieriana growing in Iran. Pharmacogn Mag 2009;5:122- 6.

39. Tanaka M, Kuei CW, Nagashima Y, Taguchi T. Application of antioxidative Maillard reaction products from histidine and glucose to sardine products. Nippon Suisan Gakkaishi 1988;54:1409-4. 